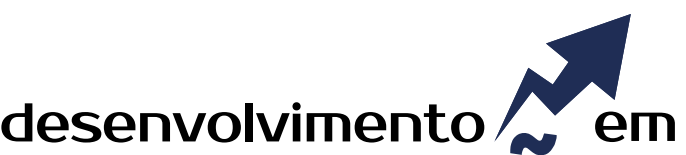 QUESTÂO
}

\section{Externalidade Florestal: \\ Caracterizações e Soluções Provenientes das Legislações Florestais Brasileiras e dos Acordos Internacionais sobre Meio Ambiente}

\author{
http://dx.doi.org/10.21527/2237-6453.2020.54.143-163
}

Recebido em: 24/9/2019

Aceito em: $27 / 10 / 2020$

\section{Mauricio João Atamanczuk ${ }^{1}$, Rodolfo Coelho Prates ${ }^{2}$}

\begin{abstract}
RESUMO
A externalidade ambiental é o prejuízo (ou benefício) relacionado às questões ambientais causado pela atividade econômica de indivíduos que não estão envolvidos na relação de transação. As externalidades florestais são caracterizadas pela relação com as florestas, seja em virtude das atividades exercidas ou em razão dos benefícios ou prejuízos causados a estas e aos seus serviços ambientais. Esta pesquisa objetiva caracterizar as externalidades florestais e apontar os mecanismos de solução a partir de dois grupos de documentos: os acordos internacionais e relatórios de eventos de abrangência mundial organizados por Órgãos da ONU; e a legislação brasileira sobre floresta. A pesquisa foi conduzida por meio de análise documental. Os resultados demonstram a associação da externalidade florestal com a forma de uso dos recursos florestais e do solo. Observa-se algumas características essenciais desta externalidade, bastante semelhante nos dois conjuntos de documentos, apesar da forma distinta de abordagem. Estas características referem-se: a) ao equilíbrio dinâmico das externalidades florestais; b) às externalidades positiva que estão associadas aos serviços ambientais ou à redução da pressão às florestas plantadas; c) à solução das questões ambientais vinculadas às florestas predominantemente a partir da regulamentação e subvenção; d) à pecuniariedade caracterizada somente para a escassez dos produtos florestais comercializados, como lenha e madeira; e) configuração complexa para a solução dos problemas climáticos; apesar de que pode ocorrer mediante mais de um mecanismo de solução de externalidade, entre eles o mercado.
\end{abstract}

Palavras-chave: Externalidade. Floresta. Nova economia institucional. Lei. Tratados internacionais.

\section{FOREST EXTERNALITY: CHARACTERIZATION AND SOLUTIONS FROM BRAZILIAN FOREST LAWS AND INTERNATIONAL ENVIRONMENT AGREEMENTS}

\begin{abstract}
The environmental externality is the loss (or benefit) related to environmental issues, caused by the economic activity of individuals who are not involved in this trading relationship. Forest externalities are characterized by the relationship with the forests, either as a result of activities carried out or due to the benefits or harm caused to them and as well as to their environmental services. The purpose of this paper is to characterize as forest externalities and to describe the mechanisms of solution based on two groups of documents: (i) international agreements and reports of world events organized by UN agencies; (ii) Brazilian forest legislation. The results demonstrate the association of forest externalities with the way the forest resources and soil are used. It is observed some essential characteristics of this external quite similar in both sets of documents, despite their different approaches. These features refer to: a) dynamic balance of forest externalities; $b$ ) the positive externalities are associated with environmental services or the reduction of pressure over planted forests; c) Solution of environmental issues related to forests predominantly from the regulation and grant; d) Monetary issues characterized only for the shortage of forest products marketed as firewood and wood; e) complex configuration to solve climate problems; although it may be settled off by more than one external mechanism of solution, including the market.
\end{abstract}

Keywords: Externality. Forest. New Institutional Economics. Law. International treaties.

\footnotetext{
${ }^{1}$ Autor correspondente. Universidade Estadual do Centro-Oeste (Unicentro). R. Salvatore Renna, 875 - Santa Cruz. CEP 85015-430. Guarapuava/PR, Brasil. http://lattes.cnpq.br/9824268420933826. http://dx.doi.org/10.21527/2237-6453.2020.54.123-142 mauricioata@yahoo.com.br

2 Universidade da Região de Joinville (Univille). Joinville/SC, Brasil.
} 
Desde o final da década de 60 e início da de 70 do século 20, a sociedade de alguns países percebeu, com maior ênfase, os problemas ambientais decorrentes das atividades econômicas, o que promoveu a intensificação dos debates e disputas políticas em torno da questão ambiental (NOBRE, 1999; PIGA; MANSANO, 2015). Essa percepção decorre, em parte, de que os recursos naturais têm sido utilizados sem considerar seus efeitos de longo prazo ao ecossistema do planeta ou sem refletir sobre as potenciais perdas para as gerações futuras (SIEBERT, 2008).

Dentre os recursos naturais afetados pelo desenvolvimento econômico, sobretudo pelo avanço das atividades agropecuárias, extrativistas e de silvicultura, estão as florestas. Elas exercem papel importante na conservação do ciclo hidrológico, são habitats de diversas espécies da fauna e contribuem para a regulação do clima e para a mitigação do aquecimento global, por exemplo. O desmatamento implica problemas ambientais críticos não somente para a população do seu entorno, mas afeta ambientes distantes com questões relativas à mitigação do aquecimento global e manutenção do regime de chuvas (FEARNSIDE, 2006; NOBRE, 2014).

Os prejuízos causados ao meio ambiente, decorrentes da atividade econômica, podem ser designados como externalidades. A externalidade ocorre quando um indivíduo produz um bem ou serviço para outro e ocasiona prejuízos ou benefícios para terceiros, ou seja, para indivíduos que não estão inseridos diretamente no processo de transação. A característica essencial da externalidade é que ela não pode ser mensurada pelo sistema de preço. O conceito é baseado na relação entre custo privado e custo social. O custo privado é aquele assumido pelo produtor do bem ou serviço no momento de sua produção, e o custo social é o custo (prejuízo) que é assumido por terceiros que não participam da transação (PIGOU, 1920).

Esta pesquisa estudou as externalidades florestais, as quais são caracterizadas pela geração de prejuízos ou benefícios das atividades econômicas que possuem relação com as florestas. As atividades econômicas podem ter relação direta com as externalidades, como nas atividades de exploração madeireira ou de produtos florestais em que há corte da vegetação. Neste caso são reconhecidos os prejuízos ambientais, mas também podem ter relação indireta como quando ocorre a mudança do uso do solo por intermédio da conversão das florestas em áreas de pastagem ou agricultura e vice-versa. Por exemplo, o estudo de Bottaro et al. (2018) identificou que a perda de parcela de terra para outros usos, quando a terra é destinada ao reflorestamento, é percebida pelos produtores rurais como uma externalidade negativa. Além disso, as florestas possuem condições de absorver prejuízos ambientais causados por outras atividades econômicas, como por meio da absorção da poluição do ar, como é o caso do sequestro de carbono.

Caracterizar as peculiaridades das externalidades florestais é necessário para buscar soluções adequadas para os problemas do custo social decorrente dela, seja mediante os mecanismos de mercado ou dos mecanismos institucionais. Diante desta necessidade, o presente artigo objetiva caracterizar a externalidade florestal e as formas de solução apresentadas em dois grupos de documentos: os acordos e relatórios de eventos internacionais sobre meio ambiente e a legislação brasileira sobre florestas. 
A pesquisa delimita-se ao conceito atribuído à externalidade e às soluções apontadas pelos dois conjuntos de documentos. Não se pretende, portanto, analisar a efetividade da aplicação da legislação ou dos documentos internacionais.

Diante do papel das florestas e dos recursos florestais na solução dos problemas ambientais, o trabalho justifica-se pela importância da compreensão das características e da forma de tratamento dado a estas externalidades pelos conjuntos de documentos analisados, uma vez que estes documentos representam os instrumentos legais oriundos de acordos internacionais e da legislação específica para o assunto.

Para alcançar o objetivo proposto, o presente artigo está organizado em cinco seções. Além desta introdução, apresenta, no seu referencial teórico, os conceitos de externalidade e de externalidade ambiental, abordados a partir da Nova Economia Institucional (NEI). A metodologia expõe a forma de condução da pesquisa. O tópico Análise dos Resultados traz a caracterização da externalidade florestal e a elucidação das formas de tratamento destas indicadas em cada um dos grupos de documentos analisados, e, posteriormente, apresenta a análise conjunta dos resultados. As considerações finais sintetizam os resultados obtidos, seguidas das referências bibliográficas consultadas.

\section{REVISÃO DE LITERATURA}

O conceito de externalidade é introduzido na economia inicialmente por Pigou (1920), que analisa a diferença entre produto social e produto privado e estabelece, para uma das condições de sua análise, a seguinte situação: uma pessoa A, na prestação de algum serviço à pessoa $B$, pelo qual recebe pagamento, presta também um serviço ou desserviço a outra pessoa não envolvida na transação, sem exigência de pagamentos ou realização de compensações ao afetado.

A externalidade compõe, portanto, os efeitos, econômicos ou não, de uma ação (produção, transação ou consumo) para agentes que não estão envolvidos nesta ação. Podem ser positivas, como as consequências de melhorias em sua casa para a propriedade do vizinho, ou negativas, como a poluição do ar gerada por uma fábrica. Do ponto de vista econômico, as externalidades não são incorporadas pelas partes envolvidas na transação, sendo, então, suportadas por partes que não as criaram (BARNES, 2009).

As externalidades podem ser classificadas em diversas categorias de acordo com as características analisadas dos seus efeitos. A classificação de maior relevância é quanto aos tipos de efeitos (positivo, quando gera benefícios, ou negativo, quando gera prejuízos), tendo em vista que a mesma é citada na definição do conceito proposto por Pigou (1920). Para a questão florestal, as externalidades positivas estão associadas, por exemplo, a contribuições para o crescimento econômico, serviços ambientais, disponibilidade futura e manutenção dos potenciais usos da floresta. As externalidades negativas associam-se à erosão de solo e perda da biodiversidade (MERLO; BRIALES, 2000).

Outra classificação refere-se à pecuniariedade. A externalidade pecuniária trata dos efeitos que a interação entre agentes causa no preço de mercado de um bem enquanto a externalidade não pecuniária não transmite seus efeitos por meio do sistema de preços. A externalidade pecuniária modifica os preços de mercado, mas sua presença não gera ineficiência na alocação de recursos, desde que os mercados sejam compe- 
titivos (HOLCOMBE; SOBEL, 2001). Caso considere-se que a externalidade deve ocorrer fora do mercado, não há classificação quanto à pecuniariedade, pois não há falha de mercado.

A classificação quanto ao equilíbrio estabelece a diferença entre externalidade estática e dinâmica. Esta classificação é importante para a questão ambiental. A estática é específica, localizada e reversível, enquanto a externalidade dinâmica provoca "efeitos ecológicos prolongados" (PEARCE, 1976 apud FAUCHEUX; NOËL, 1995, p. 220). A escassez de peixes para um agente em razão da sobrepesca praticada por outro agente em local de acesso aberto, exemplifica os efeitos ecológicos estáticos, pois o efeito é imediato. A pesca predatória de filhotes de peixes por um agente exemplifica os efeitos ecológicos dinâmicos ou futuros (ASAFU-ADJAYE, 2005).

A solução para o problema de externalidade pode ocorrer com o auxílio de instrumentos econômicos ou não econômicos de política ambiental. Dentre os instrumentos econômicos, cita-se: taxação, subvenção, negociação voluntária entre as partes e o mercado do direito de poluir. Os instrumentos não econômicos são a regulamentações e normas (FAUCHEUX; NOËL, 1995).

A taxação, ou solução fiscal, é a solução pigouviana para a externalidade, a qual atribui ao agente causador a responsabilidade de reparação do dano (PIGOU, 1920). Refere-se à imposição de uma taxa ao poluidor para que este incorpore em seus gastos o valor dos custos sociais gerados pela sua atividade econômica. $O$ valor arrecadado com a taxação deve ser aplicado na subvenção de atividades geradoras de externalidades positivas para compensação da externalidade das atividades sujeitas a esta (VARIAN, 1992).

Coase (1960), por outro lado, apresenta a natureza recíproca deste problema da externalidade. Quer se evitar que uma fábrica $A$ cause prejuízo ao vizinho B pela emissão de fumaça. Ao evitar tal prejuízo, contudo, faz com que $B$ imponha prejuízo à $A$. Deveria levar-se em consideração o direito do vizinho de causar prejuízo à fábrica ao impor a ela o tratamento ou restrições na emissão de fumaça. Há, portanto, a necessidade de definir adequadamente os direitos de propriedade, conhecendo previamente se o direito favorece o agente $A$ ou o $B$.

Ao desenvolver sua análise para a questão ambiental, Paavola e Adger (2002) explicam a diferença fundamental das abordagens de Pigou e Coase. Pigou considerou o problema ambiental como externalidade unidirecional, no qual a solução é dada pela imposição de uma taxa ao poluidor, taxa esta que subsidia as externalidades positivas a fim de gerar equilíbrio de mercado. Coase reconhece que a solução pode vir pela atribuição dos direitos de propriedade a uma das partes ou por meio da regulamentação ambiental (PAAVOLA; ADGER, 2002). A diferença também pode ser relacionada com a natureza dos agentes envolvidos na solução da externalidade: para Pigou (1920), a relação é estabelecida entre o agente individual privado e o Estado (regulador); para Coase (1960), a solução ocorre a partir da relação entre agentes individuais privados.

Desta perspectiva surgem soluções às externalidades, como o acordo voluntário entre as partes. $\mathrm{O}$ emissor da externalidade indeniza a vítima quando os custos da indenização são menores que os custos para evitar a externalidade. Quando não há responsabilização pela externalidade, a vítima pode indenizar o emissor para que este evite a poluição, desde que este valor seja inferior ao custo para tratar a externalidade (COASE, 1960). 
Para o caso da externalidade negativa, a indenização paga pela vítima ao poluidor pode ser considerada um tipo de subvenção. Neste caso, o poluidor é compensado para não realizar a atividade causadora da externalidade. Os incentivos pagos aos agentes poluidores/produtores geram redução da produção e, consequentemente, da poluição. A redução da oferta, contudo, pode impactar em aumento dos preços dos produtos, incentivando a retomada do crescimento da produção e, consequentemente, o aumento da poluição (FAUCHEUX; NOËL, 1995).

Ainda em relação aos instrumentos econômicos, o mercado do direito de poluir é uma alternativa. Este é dependente da definição dos direitos de propriedade sobre os bens ambientais. Cabe ao regulador determinar os níveis de poluição aceitáveis e emitir títulos de poluição. Estes títulos são negociados pelos geradores da poluição. Os preços dos mesmos serão inferiores ao nível em que seja mais vantajoso realizar a despoluição ou que inviabilizem a produção (MANKIW, 2005).

Conforme Nusdeo (2008), a comercialização dos direitos de poluição, ou a certificação de emissões de carbono, refere-se à apropriação de um bem caracterizado anteriormente como bem livre. O mecanismo cap-and-trade pode ser usado para exemplificar as emissões certificadas como instrumento de mercado de permissões para poluir. Godoy e Saes (2015) realizaram estudo comparativo da aplicação do cap-and-trade e Mecanismo de Desenvolvimento Limpo (MDL) na União Europeia. Constataram que estes instrumentos se destacam pelo volume e visibilidade em relação ao surgimento de outros instrumentos. As dificuldades para o mercado de emissões são decorrentes das incertezas quanto às metas globais de redução de emissão.

A solução da externalidade pode ocorrer também por intermédio da atuação direta do governo. Instituir adequadamente os direitos de propriedade e a regulamentação ambiental é necessário para resolver conflitos de interesses entre agentes, além disso é importante ainda eliminar os custos de transação existentes em razão da complexidade de solução por meio de mecanismos de mercado (MILGROM; ROBERTS: 1992; PAAVOLA; ADGER, 2002). A proteção ambiental mediante a regulamentação, determina a forma de execução, as proibições e as obrigações das atividades econômicas. Pode-se proibir o despejo no ambiente de determinados produtos, limitar a emissão de poluentes ou obrigar o uso de instrumentos para produção de determinados bens ou para a despoluição (MANKIW, 2005).

O ambiente favorável para o tratamento da externalidade por meio da regulamentação possui definição de convenções comuns sobre o problema central, informações de senso comum, baixa heterogeneidade dos agentes, fraca expectativa de inovação técnica e elevada expectativa de normalização. Quando as condições são opostas os instrumentos econômicos são mais adequados (FAUCHEUX; NOËL, 1995).

A eficiência da escolha dos instrumentos deve considerar a condição da externalidade. Segundo Bithas (2011), a externalidade ambiental afeta indivíduos em três condições: a) os indivíduos que pertencem ao mesmo quadro institucional (agressores e afetados pertencem ao mesmo sistema econômico); b) as gerações futuras; c) os indivíduos localizados espacialmente distantes. As externalidades dos dois últimos grupos de indivíduos não podem ser refletidas nas estimativas monetárias de externalidade ambiental, por isso a alocação de recursos não renováveis de forma intergeracional deve 
ser feita a partir da preservação do direito ambiental. Os governos tornam-se agentes importantes na formação das instituições que objetivam a solução das externalidades mediante a escolha dos instrumentos de política ambiental.

Na perspectiva das externalidades florestais, vários estudos e abordagens podem ser considerados. Merlo e Briales (2000) discutiram as externalidades das florestas do mediterrâneo. A conservação do solo e a preservação da água são aspectos importantes de externalidade na floresta mediterrânea e a regulação não aconteceu em razão da madeira como ocorreu em outras regiões europeias. A produção de madeira não foi negligenciada, mas é considerada, em conjunto com a conversão de solo em pastagens, causa das externalidades negativas.

Price (2007) estudou a certificação florestal para a internalização das externalidades pecuniárias. Para o autor, o uso sustentável da floresta pode impor externalidades pecuniárias relativas à mudança de preço no mercado, e a certificação pode ser a forma de internalizar a externalidade ambiental oriunda do manejo sustentável.

O estudo de Soliño, Prada e Vázquez (2009) descreve como possíveis externalidades positivas, decorrentes do manejo sustentável para a geração de energia pelo uso da biomassa, a diminuição de $\mathrm{CO}_{2}$ e outros gases poluentes e a redução de problemas ambientais, como erosão e desertificação, incêndios, pragas e doenças.

Dois pontos importantes são destacados por Richards (2000) quando se trata dos direitos de propriedade para assegurar a conservação das florestas e proporcionar as externalidades positivas decorrentes: a) o mercado deve tornar a conservação da floresta uma condição atraente para o uso da terra; b) as terras sem vegetação têm maior valor do que as terras florestais como decorrência das legislações fundiárias. Esses dois elementos se entrelaçam com o conceito de desenvolvimento sustentável. Para Bithas (2011), a sustentabilidade, ou o desenvolvimento sustentável, é caracterizada pela internalização das externalidades, ou seja, a ausência de externalidade.

Por fim, Lemos, Vital e Pinto (2010) estudaram o papel das florestas no Brasil para cumprimento das metas do Protocolo de Quioto. Os autores observaram como externalidade positiva a absorção de gases de efeito estufa oriunda das áreas de reflorestamento, e como externalidade negativa as emissões destes gases oriundas do desmatamento. Citam o MDL e a Redução de Emissões por Desmatamento e Degradação (REDD) como mecanismos para financiar atividades de reflorestamento e conservação das florestas. O MDL é o mecanismo de mercado que comercializa créditos oriundos das atividades que promovem a remoção de gás carbônico da atmosfera, sendo elegíveis para a questão florestal, projetos de florestamento e reflorestamento. O REDD tem o objetivo de reduzir a emissão de gases de efeito estufa por desmatamento e degradação florestal. A redução do desmatamento permite a emissão de papéis negociáveis de Redução de Emissão Certificadas, comercializados no mercado de carbono.

\section{METODOLOGIA}

Para o alcance do objetivo desta investigação adotou-se a pesquisa documental (GODOY; 1995). Foram elencados dois conjuntos de documentos atentando-se para a relevância ou representatividade sobre a temática investigada (GODOY, 1995; FLICK, 2009) e a representação de caráter oficial de informação da organização que o emitiu (CORBETTA, 2003). 
O primeiro conjunto trata de documentos, de abrangência mundial, emitidos por órgãos da Organização das Nações Unidas (ONU) em relação às questões ambientais e, principalmente, sobre as florestas. Considerou-se a relevância de eventos e acordos internacionais como desencadeadores de mudanças de concepções que podem levar às alterações institucionais.

O recorte temporal para a seleção dos documentos inicia-se no ano de 1972, quando houve a realização da primeira Conferência Mundial sobre Meio Ambiente organizada pela ONU, encerrando-se no ano de 2014.

Optou-se por realizar a divisão dos documentos em razão dos seus objetivos e abrangência nos seguintes grupos: Declarações das conferências mundiais; Biodiversidade; Mudança climática; Debates sobre florestas; e Comércio de madeiras, conforme Quadro 1.

\section{Quadro 1 - Documentos Internacionais}

\begin{tabular}{|c|c|c|}
\hline Grupo & ANO & Evento ou Instituição de Origem \\
\hline \multirow{4}{*}{$\begin{array}{l}\text { Declarações } \\
\text { das } \\
\text { Conferências }\end{array}$} & 1972 & $\begin{array}{l}\text { Declaração da Conferência das Nações Unidas para o Meio Ambiente Humano } \\
\text { (CNUMAH) - Estocolmo, Suécia. }\end{array}$ \\
\hline & 1992 & $\begin{array}{l}\text { Declaração do Rio de Janeiro sobre Meio Ambiente e Desenvolvimento da } \\
\text { Conferência das Nações Unidas sobre o Meio Ambiente e Desenvolvimento } \\
\text { (CNUMAD) - Rio de Janeiro, Brasil. }\end{array}$ \\
\hline & 2002 & $\begin{array}{l}\text { Declaração de Joanesburgo sobre Desenvolvimento Sustentável da Cúpula } \\
\text { Mundial sobre Desenvolvimento Sustentável (CMDS), Rio+10 - Joanesburgo, } \\
\text { África do Sul. }\end{array}$ \\
\hline & 2012 & $\begin{array}{l}\text { Relatório "O futuro que queremos" da Conferência das Nações Unidas sobre } \\
\text { Desenvolvimento Sustentável (CNUDS), Rio + } 20 \text { - Rio de Janeiro, Brasil. }\end{array}$ \\
\hline Biodiversidade & 1992 & $\begin{array}{l}\text { Convenção sobre a Diversidade Biológica da Conferência das Nações Unidas } \\
\text { sobre o Meio Ambiente e Desenvolvimento (CNUMAD) - Rio de Janeiro, } \\
\text { Brasil. }\end{array}$ \\
\hline \multirow{4}{*}{$\begin{array}{l}\text { Mudança } \\
\text { Climática }\end{array}$} & 1992 & $\begin{array}{l}\text { Convenção-Quadro das Nações Unidas sobre Mudança do Clima (CQNUMC) } \\
\text { da CNUMAD - Rio de Janeiro, Brasil. }\end{array}$ \\
\hline & 1997 & Decisão 1/CP.3 da Conferência das Partes da CQNUMC (COP.3) \\
\hline & 2001 & $\begin{array}{l}\text { Decisão 5/CP.6 - COP.6-II, 2001: Acordo do Bonn da Conferência das Partes da } \\
\text { CQNUMC (COP.6). }\end{array}$ \\
\hline & 2008 & $\begin{array}{l}\text { Decisão 1/CP13: Plano de Ação de Bali da Conferência das Partes da CQNUMC } \\
\text { (COP.13). }\end{array}$ \\
\hline \multirow{7}{*}{$\begin{array}{l}\text { Debates sobre } \\
\text { Florestas }\end{array}$} & 1992 & $\begin{array}{l}\text { Agenda 21, Capítulo 11: Combate ao Desmatamento da CNUMAD - Rio de } \\
\text { Janeiro, Brasil. }\end{array}$ \\
\hline & 1992 & Declaração de Princípios sobre Florestas da CNUMAD - Rio de Janeiro, Brasil. \\
\hline & 1996 & $\begin{array}{l}\text { Informe do Painel Intergovernamental sobre Florestas (sigla em inglês IPF) } \\
\text { sobre seu segundo período de sessão. }\end{array}$ \\
\hline & 1999 & $\begin{array}{l}\text { Informe do Fórum Intergovernamental sobre Florestas (sigla em inglês IFF) } \\
\text { relativo ao seu terceiro período de sessões. }\end{array}$ \\
\hline & 2000 & Informe do IFF relativo ao seu quarto período de sessões. \\
\hline & 2013 & $\begin{array}{l}\text { Resolução } 10 / 2 \text { do Fórum das Nações Unidas sobre Florestas (sigla em inglês } \\
\text { UNFF). }\end{array}$ \\
\hline & 2007 & $\begin{array}{l}\text { Resolução 062/98 - Juridicamente não vinculante sobre florestas da } \\
\text { Assembleia Geral da ONU. }\end{array}$ \\
\hline \multirow{3}{*}{$\begin{array}{l}\text { Comércio de } \\
\text { Madeiras }\end{array}$} & 1983 & $\begin{array}{l}\text { Acordo Internacional de Madeiras Tropicais de } 1983 \text { da Conferência das } \\
\text { Nações Unidas Sobre Comércio e Desenvolvimento (CNUCD). }\end{array}$ \\
\hline & 1994 & Acordo Internacional de Madeiras Tropicais de 1994 da CNUCD. \\
\hline & 2006 & Acordo Internacional de Madeiras Tropicais de 2006 da CNUCD. \\
\hline
\end{tabular}

Fonte: Dados da pesquisa (2018). 
O segundo grupo de documentos é constituído por Leis Federais, Medidas Provisórias e Decretos de âmbito federal brasileiro promulgados a partir de 1965, quando houve a aprovação do Código Florestal Brasileiro, instituído pela Lei 4.771 (BRASIL, 1965), encerrando-se no ano de 2014. Os documentos foram obtidos mediante a busca no sítio da internet do Poder Executivo Federal (www.planalto.gov.br) por meio dos seguintes termos: floresta; florestal; desmatamento; florestamento; e desflorestamento. Após a busca, selecionou-se somente aqueles documentos relacionados com o objetivo deste trabalho, em virtude da representatividade da legislação. A amostra é apresentada no Quadro 2.

Quadro 2 - Legislação Brasileira

\begin{tabular}{|c|c|c|c|}
\hline Ato & Data & Súmula & Assunto \\
\hline LEI 4.771/1965* & $15 / 9 / 1965$ & Institui/altera o Código Florestal. & \multirow{2}{*}{ Código Florestal } \\
\hline LEI $12.651 / 2012$ & $25 / 5 / 2012$ & Institui/altera o Código Florestal. & \\
\hline LEI 5.106/1966 & 2/9/1966 & $\begin{array}{l}\text { Incentivos fiscais concedidos a empreendimentos } \\
\text { florestais. }\end{array}$ & Incentivo Fiscal \\
\hline LEI 6.902/1981 & $27 / 4 / 1981$ & $\begin{array}{l}\text { Criação de estações ecológicas, áreas de proteção } \\
\text { ambiental. }\end{array}$ & \multirow{5}{*}{$\begin{array}{l}\text { Áreas } \\
\text { Protegidas }\end{array}$} \\
\hline DEC 1.298/1994 & $27 / 10 / 1994$ & Regulamento das Florestas Nacionais. & \\
\hline DEC $1.922 / 1996$ & $5 / 6 / 1996$ & Reservas Particulares do Patrimônio Natural. & \\
\hline LEI 9.985/2000 & $18 / 7 / 2000$ & $\begin{array}{l}\text { Sistema nacional de Unidades de Conservação da } \\
\text { Natureza. }\end{array}$ & \\
\hline LEI $11.284 / 2006$ & $2 / 3 / 2006$ & $\begin{array}{l}\text { Gestão de Florestas Públicas; Serviço } \\
\text { Florestal Brasileiro (SFB) e Fundo Nacional de } \\
\text { Desenvolvimento Florestal (FNDF). }\end{array}$ & \\
\hline LEI 9.605/1998 & $12 / 2 / 1998$ & $\begin{array}{l}\text { Sanções penais e administrativas a atividades lesivas } \\
\text { ao meio ambiente. }\end{array}$ & $\begin{array}{l}\text { Crimes } \\
\text { Ambientais }\end{array}$ \\
\hline LEI 11.428/2006 & $22 / 12 / 2006$ & Proteção do bioma Mata Atlântica. & Mata Atlântica \\
\hline LEI 6.938/1981 & $31 / 8 / 1981$ & Política Nacional do Meio Ambiente. & \multirow{5}{*}{$\begin{array}{l}\text { Políticas } \\
\text { Nacionais }\end{array}$} \\
\hline LEI $12.187 / 2009$ & $29 / 12 / 2009$ & Política Nacional sobre Mudança do Clima - PNMC. & \\
\hline LEI $12.805 / 2013$ & $29 / 4 / 2013$ & $\begin{array}{l}\text { Política Nacional de Integração Lavoura-Pecuária- } \\
\text { Floresta. }\end{array}$ & \\
\hline LEI $12.854 / 2013$ & $26 / 8 / 2013$ & $\begin{array}{l}\text { Recuperação florestal e Sistemas Agroflorestais em } \\
\text { áreas rurais desapropriadas e em áreas degradadas. }\end{array}$ & \\
\hline DEC 8.375/2014 & $11 / 12 / 2014$ & Política agrícola para florestas plantadas. & \\
\hline
\end{tabular}

Fonte: Dados da pesquisa (2018).

Para o desenvolvimento da análise considerou-se que a floresta não produz externalidades per se. As externalidades são oriundas das atividades econômicas baseadas no uso da terra ou dos recursos florestais, que causam a destruição ou degradação das florestas ou são exercidas considerando a conservação das mesmas, proporcionando garantias da prestação dos serviços ambientais (MERLO; BRIALES, 2000).

Para a análise realizou-se a leitura para a identificação de sentenças que se referiam a benefícios ou prejuízos ambientais ocasionados a partir de ação de degradação ou de conservação das floresta e sentenças, que diziam respeito às florestas como fonte de solução para problemas ocasionados por atividades econômicas relacionadas, de alguma forma, com a floresta. Os benefícios ou prejuízos que puderam ser vinculados às atividades comerciais e não se caracterizam como produto comercial destas, foram definidos como externalidades. A partir das informações obtidas realizou-se a classificação 
da externalidade nos aspectos possíveis quanto a: tipo de efeito (positivo ou negativo), pecuniariedade (pecuniária ou não pecuniária) e equilíbrio (estática ou dinâmica) (FAUCHEUX; NOËL, 1995).

Ainda, considerando as informações obtidas, buscou-se determinar qual a forma de solução proposta para as externalidades, levando-se em conta os instrumentos econômicos e não econômicos, conforme apresentados na revisão de literatura. Os instrumentos econômicos foram classificados a partir do mecanismo empregado, os quais são: subvenção, taxação, livre-negociação e mercado de direitos de poluir. Os instrumentos não econômicos são normas e regulamentos que exercem o papel de regulamentar, proibir ou obrigar as ações dos agentes econômicos.

Por fim, realizou-se a comparação entre as caracterizações de externalidades obtidas em cada documento para o conjunto a que pertencem e a comparação entre os dois conjuntos de documentos, buscando evidenciar semelhanças e diferenças a partir das categorias elencadas para a análise.

\section{DESCRIÇÃO E ANÁLISE DOS RESULTADOS}

O tópico de descrição e análise de resultados foi divido em três seções. A primeira e a segunda constituem a descrição dos resultados. Na primeira seção é apresentada a caracterização e as formas de tratamento das externalidades florestais apontadas nos documentos oriundos de eventos e acordos internacionais selecionados para a análise. A segunda seção traz a caracterização e a forma de tratamento das externalidades identificadas na legislação brasileira vinculada à floresta. A terceira desenvolve a análise a partir do comparativo entre os resultados objetivos para os dois conjuntos de documentos.

\section{Externalidade nos Documentos Internacionais}

A análise desenvolvida neste tópico objetiva caracterizar a externalidade florestal e, principalmente, as formas de solução identificadas nos documentos internacionais selecionados para a pesquisa. Os resultados são apresentados no quadro a seguir. Após, discorre-se, de forma explicativa, sobre cada conjunto de documentos e externalidades identificadas.

Quadro 3 - Externalidades nos documentos internacionais

\begin{tabular}{|c|c|c|c|c|}
\hline Documento & Externalidade & Causa associada & Classificação & Tratamento \\
\hline $\begin{array}{l}\text { Declaração das } \\
\text { Conferências 1972, 1992, } \\
2002 \text { e } 2012\end{array}$ & $\begin{array}{l}\text { Indisponibilidade } \\
\text { de recursos } \\
\text { naturais }\end{array}$ & $\begin{array}{l}\text { Atividades do } \\
\text { desenvolvimento } \\
\text { econômico }\end{array}$ & $\begin{array}{l}\text { Negativa; não } \\
\text { pecuniária; } \\
\text { dinâmica }\end{array}$ & $\begin{array}{l}\text { Regulamentação, } \\
\text { Taxação e Subvenção } \\
\text { e Mercado }\end{array}$ \\
\hline $\begin{array}{l}\text { Convenção sobre } \\
\text { Diversidade Biológica } \\
1992\end{array}$ & $\begin{array}{l}\text { Degradação } \\
\text { do patrimônio } \\
\text { genético }\end{array}$ & $\begin{array}{l}\text { Atividades do } \\
\text { desenvolvimento } \\
\text { econômico }\end{array}$ & $\begin{array}{l}\text { Negativa, não } \\
\text { pecuniária, } \\
\text { dinâmica ou } \\
\text { estática }\end{array}$ & Regulamentação \\
\hline $\begin{array}{l}\text { Protocolo de Quioto, } \\
\text { 1997, Convenção Quadro } \\
\text { das Nações Unidas sobre } \\
\text { Mudança Climática, } \\
\text { Decisão 1/CP13; Decisão } \\
\text { 2/CP.13 }\end{array}$ & $\begin{array}{l}\text { Efeito negativo } \\
\text { no clima em } \\
\text { função da } \\
\text { emissão de gases } \\
\text { de efeito estufa }\end{array}$ & Desmatamento & $\begin{array}{l}\text { Negativa, não } \\
\text { pecuniária, } \\
\text { dinâmica }\end{array}$ & $\begin{array}{l}\text { Subvenção, } \\
\text { Regulamentação e } \\
\text { Mercado do Direito } \\
\text { de Poluir }\end{array}$ \\
\hline
\end{tabular}




\begin{tabular}{|c|c|c|c|c|}
\hline $\begin{array}{l}\text { Protocolo de Quioto, } \\
\text { 1997, Convenção Quadro } \\
\text { das Nações Unidas sobre } \\
\text { Mudança Climática, } \\
\text { Decisão 5/CP.6-II }\end{array}$ & $\begin{array}{l}\text { Efeito positivo no } \\
\text { clima em razão } \\
\text { da absorção de } \\
\text { gases de efeito } \\
\text { estufa }\end{array}$ & $\begin{array}{l}\text { Florestamento e } \\
\text { reflorestamento }\end{array}$ & $\begin{array}{l}\text { Positiva, não } \\
\text { pecuniária, } \\
\text { dinâmica }\end{array}$ & $\begin{array}{l}\text { Mercado do } \\
\text { Direito de Poluir e } \\
\text { Regulamentação }\end{array}$ \\
\hline Agenda 21 & $\begin{array}{l}\text { Redução } \\
\text { dos serviços } \\
\text { ambientais }\end{array}$ & $\begin{array}{l}\text { Degradação } \\
\text { florestal }\end{array}$ & $\begin{array}{l}\text { Negativa, Não } \\
\text { pecuniária, } \\
\text { dinâmica }\end{array}$ & $\begin{array}{l}\text { Regulamentação e } \\
\text { subvenção }\end{array}$ \\
\hline $\begin{array}{l}\text { Agenda } 21 \text { (1992); } \\
\text { Declaração dos } \\
\text { Princípios sobre } \\
\text { Florestas (1992); IPF } \\
2 \text { (1996); IFF } 3 \text { (1999); } \\
\text { UNFF (2013); Assembleia } \\
\text { Geral da ONU (2007) }\end{array}$ & $\begin{array}{l}\text { Manutenção } \\
\text { dos serviços } \\
\text { ambientais }\end{array}$ & $\begin{array}{l}\text { Atividades } \\
\text { de manejo } \\
\text { sustentável }\end{array}$ & $\begin{array}{l}\text { Positiva, não } \\
\text { pecuniária, } \\
\text { dinâmica }\end{array}$ & $\begin{array}{l}\text { Regulamentação e } \\
\text { subvenção }\end{array}$ \\
\hline $\begin{array}{l}\text { Agenda } 21 \text { (1992) e } \\
\text { Declaração de Princípios } \\
\text { sobre Florestas (1992) }\end{array}$ & $\begin{array}{l}\text { Diminuição } \\
\text { da pressão } \\
\text { sobre florestas } \\
\text { primárias } \\
\end{array}$ & $\begin{array}{l}\text { Reflorestamento } \\
\text { ou florestas } \\
\text { plantadas }\end{array}$ & $\begin{array}{l}\text { Positiva, não } \\
\text { pecuniária, } \\
\text { estática }\end{array}$ & $\begin{array}{l}\text { Regulamentação e } \\
\text { subvenção }\end{array}$ \\
\hline $\begin{array}{l}\text { Acordo de Madeiras } \\
\text { Tropicais }(1983,1994, \\
\text { 2006) }\end{array}$ & $\begin{array}{l}\text { Redução da } \\
\text { disponibilidade } \\
\text { de recursos } \\
\text { florestais } \\
\text { madeireiros }\end{array}$ & $\begin{array}{l}\text { Exploração } \\
\text { excessiva de } \\
\text { madeira }\end{array}$ & $\begin{array}{l}\text { Negativa, } \\
\text { dinâmica, } \\
\text { pecuniária }\end{array}$ & $\begin{array}{l}\text { Subvenção e } \\
\text { Regulamentação }\end{array}$ \\
\hline $\begin{array}{l}\text { Acordo de Madeiras } \\
\text { Tropicais }(1983,1994, \\
\text { 2006) }\end{array}$ & $\begin{array}{l}\text { Prejuízos } \\
\text { ambientais }\end{array}$ & $\begin{array}{l}\text { Exploração } \\
\text { excessiva de } \\
\text { madeira }\end{array}$ & $\begin{array}{l}\text { Negativa, } \\
\text { dinâmica } \\
\text { e não } \\
\text { pecuniária }\end{array}$ & $\begin{array}{l}\text { Subvenção e } \\
\text { Regulamentação }\end{array}$ \\
\hline $\begin{array}{l}\text { Acordo de Madeiras } \\
\text { Tropicais }(1983,1994, \\
\text { 2006) }\end{array}$ & $\begin{array}{l}\text { Impacto social } \\
\text { às comunidades } \\
\text { tradicionais }\end{array}$ & $\begin{array}{l}\text { Exploração } \\
\text { excessiva de } \\
\text { madeira }\end{array}$ & $\begin{array}{l}\text { Negativa, } \\
\text { dinâmica } \\
\text { e não } \\
\text { pecuniária }\end{array}$ & \begin{tabular}{|l} 
Subvenção e \\
Regulamentação
\end{tabular} \\
\hline
\end{tabular}

Fonte: Dados da Pesquisa (2018).

Dentre os principais aspectos identificados, a indisponibilidade dos recursos e dos benefícios ambientais é reconhecida em vários documentos, mas com destaque para os relatórios das grandes conferências sobre meio ambiente. Nestes, as questões principais referem-se aos prejuízos ambientais para gerações futuras. Para isso, o tratamento da externalidade requer regulamentação específica, uma vez que a solução dos problemas para as gerações futuras não possibilita o uso dos mecanismos de mercado.

A escassez dos recursos é citada pelos Acordos Internacionais de Madeiras Tropicais em suas três edições na Conferência das Nações Unidas Sobre Comércio e Desenvolvimento (CNUCD) em 1983, 1994 e 2006. Neste caso, a característica pecuniária da externalidade é evidenciada. A principal preocupação do acordo é a disponibilidade do recurso para a exploração comercial do mesmo. O tratamento da externalidade pode ser alcançado a partir de mecanismos de mercado, uma vez que há valorização do bem desde a sua escassez, apesar de os documentos não sugerirem estes mecanismos. Neste caso haveria maior dificuldade ou impossibilidade de utilização destes recursos por agentes de menor poder econômico. A sugestão dos documentos é a subvenção e regulamentação, impulsionando, principalmente, o manejo sustentável e o reflorestamento. 
A configuração complexa, extensiva e de difícil reversibilidade da externalidade tratada nos documentos relacionados às mudanças climáticas é outra característica observada. O impacto é perceptível em um contexto global. O tratamento local pode ser insignificante para a solução do problema, contudo é necessário para que se alcance resultados satisfatórios. A multiplicidade de fontes geradoras desta externalidade negativa, tendo como impulsionador principal o desenvolvimento econômico, dificulta seu tratamento. As regulamentações para o tratamento ou a redução da geração destas externalidades, nas atividades vinculadas às florestas, esbarram na necessidade dos países subdesenvolvidos de alcançarem o desenvolvimento econômico para o bem-estar de seus cidadãos.

Os serviços ambientais são outra característica percebida a partir dos documentos internacionais. Estes aspectos estão relacionados principalmente ao capítulo $11 \mathrm{da}$ Agenda 21, à Declaração de Princípios das Florestas e aos relatórios dos Fóruns sobre Florestas. A complexidade da mensuração em razão da multiplicidade de benefícios ou prejuízos ocasionados pela geração de externalidades positivas ou negativas, respectivamente, oriundas de atividades baseadas nas florestas, dificulta a sua solução por meio de mecanismos de mercado. A atuação governamental, a partir da regulamentação e subvenção é necessária.

\section{EXTERNALIDADE NA LEGISLAÇÃO BRASILEIRA SOBRE FLORESTAS}

No grupo de documentos de legislação analisados, a visão de externalidade está associada às recomendações de solução. Neste caso, os documentos reconhecem estas para propor a forma de internalizá-las. A legislação representa a norma que estabelece a forma de solução apropriada ou define os direitos de propriedade para que se busque a solução via mercado.

As externalidades podem ser negativas quando a legislação busca solução, ou positivas quando a legislação apresenta incentivos para sua ocorrência. O Quadro 4 resume as externalidades identificadas nos documentos legais analisados.

Quadro 4 - Externalidades identificadas nos documentos legais sobre florestas

\begin{tabular}{|l|l|l|l|l|}
\hline $\begin{array}{l}\text { Categoria } \\
\text { de } \\
\text { Documento }\end{array}$ & Externalidade & $\begin{array}{l}\text { Causas } \\
\text { associadas }\end{array}$ & Classificação & Tratamento \\
\hline $\begin{array}{l}\text { Código } \\
\text { Florestal }\end{array}$ & $\begin{array}{l}\text { Prejuízos aos serviços } \\
\text { ambientais prestados pela } \\
\text { floresta }\end{array}$ & $\begin{array}{l}\text { Desmatamento, } \\
\text { degradação e } \\
\text { conversão do } \\
\text { uso do solo }\end{array}$ & $\begin{array}{l}\text { Negativa, não } \\
\text { pecuniária e } \\
\text { dinâmica }\end{array}$ & $\begin{array}{l}\text { Regulamentação, } \\
\text { subvenção e } \\
\text { mercado }\end{array}$ \\
\hline $\begin{array}{l}\text { Código } \\
\text { Florestal }\end{array}$ & $\begin{array}{l}\text { Efeito negativo no clima em } \\
\text { razão da emissão de gases } \\
\text { de efeito estufa oriundos de } \\
\text { reservatórios. }\end{array}$ & $\begin{array}{l}\text { Desmatamento, } \\
\text { degradação e } \\
\text { conversão do } \\
\text { uso do solo }\end{array}$ & $\begin{array}{l}\text { Negativa, não } \\
\text { pecuniária, dinâmica }\end{array}$ & $\begin{array}{l}\text { Regulamentação, } \\
\text { subvenção e } \\
\text { mercado }\end{array}$ \\
\hline Florestal & $\begin{array}{l}\text { disponibilidade dos } \\
\text { produtos florestais } \\
\text { madeireiros }\end{array}$ & $\begin{array}{l}\text { Exploração } \\
\text { excessiva }\end{array}$ & $\begin{array}{l}\text { Negativa, pecuniária } \\
\text { e dinâmica }\end{array}$ & $\begin{array}{l}\text { Regulamentação e } \\
\text { subvenção }\end{array}$ \\
\hline $\begin{array}{l}\text { Mata } \\
\text { Atlântica }\end{array}$ & $\begin{array}{l}\text { Extinção dos recursos da } \\
\text { Mata Atlântica }\end{array}$ & $\begin{array}{l}\text { Exploração } \\
\text { dos recursos } \\
\text { naturais }\end{array}$ & $\begin{array}{l}\text { Negativa, não } \\
\text { pecuniária e } \\
\text { dinâmica }\end{array}$ & $\begin{array}{l}\text { Regulamentação e } \\
\text { subvenção }\end{array}$ \\
\hline
\end{tabular}




\begin{tabular}{|c|c|c|c|c|}
\hline $\begin{array}{l}\text { Mata } \\
\text { Atlântica }\end{array}$ & $\begin{array}{l}\text { Redução ou } \\
\text { indisponibilidade dos } \\
\text { serviços ambientais }\end{array}$ & $\begin{array}{l}\text { Exploração } \\
\text { dos recursos } \\
\text { naturais } \\
\end{array}$ & $\begin{array}{l}\text { Negativa, não } \\
\text { pecuniária e } \\
\text { dinâmica } \\
\end{array}$ & $\begin{array}{l}\text { Regulamentação e } \\
\text { subvenção }\end{array}$ \\
\hline $\begin{array}{l}\text { Áreas } \\
\text { Protegidas }\end{array}$ & $\begin{array}{l}\text { Prejuízos aos serviços } \\
\text { ambientais }\end{array}$ & $\begin{array}{l}\text { Conversão do } \\
\text { uso do solo } \\
\text { e atividades } \\
\text { degradantes } \\
\end{array}$ & $\begin{array}{l}\text { Negativa, não } \\
\text { pecuniária e } \\
\text { dinâmica }\end{array}$ & $\begin{array}{l}\text { Diretos de } \\
\text { propriedade, } \\
\text { regulamentação e } \\
\text { subvenção } \\
\end{array}$ \\
\hline $\begin{array}{l}\text { Áreas } \\
\text { Protegidas }\end{array}$ & $\begin{array}{l}\text { Disponibilidade de serviços } \\
\text { ambientais }\end{array}$ & $\begin{array}{l}\text { Atividade } \\
\text { sustentável }\end{array}$ & $\begin{array}{l}\text { Positiva, não } \\
\text { pecuniária, dinâmica }\end{array}$ & $\begin{array}{l}\text { Diretos de } \\
\text { propriedade, } \\
\text { regulamentação e } \\
\text { Subvenção }\end{array}$ \\
\hline $\begin{array}{l}\text { Áreas } \\
\text { Protegidas }\end{array}$ & $\begin{array}{l}\text { Absorção e estoque de } \\
\text { gases de efeito estufa }\end{array}$ & $\begin{array}{l}\text { Atividade } \\
\text { sustentável }\end{array}$ & $\begin{array}{l}\text { Positiva, não } \\
\text { pecuniária, dinâmica }\end{array}$ & $\begin{array}{l}\text { Diretos de } \\
\text { propriedade, } \\
\text { regulamentação, } \\
\text { subvenção e } \\
\text { mercado } \\
\end{array}$ \\
\hline $\begin{array}{l}\text { Crimes } \\
\text { Ambientais }\end{array}$ & $\begin{array}{l}\text { Indisponibilidade dos } \\
\text { recursos naturais }\end{array}$ & $\begin{array}{l}\text { Atividades } \\
\text { degradantes }\end{array}$ & $\begin{array}{l}\text { Negativa, não } \\
\text { pecuniária e } \\
\text { dinâmica }\end{array}$ & Regulamentação \\
\hline $\begin{array}{l}\text { Políticas } \\
\text { Nacionais }\end{array}$ & Prejuízos ambientais & $\begin{array}{l}\text { Atividades } \\
\text { degradantes }\end{array}$ & $\begin{array}{l}\text { Negativa, não } \\
\text { pecuniária e } \\
\text { dinâmica } \\
\end{array}$ & $\begin{array}{l}\text { Regulamentação e } \\
\text { subvenção }\end{array}$ \\
\hline $\begin{array}{l}\text { Políticas } \\
\text { Nacionais }\end{array}$ & $\begin{array}{l}\text { Danos causados à fauna e } \\
\text { à flora }\end{array}$ & $\begin{array}{l}\text { Atividades } \\
\text { degradantes }\end{array}$ & $\begin{array}{l}\text { Negativa, não } \\
\text { pecuniária e } \\
\text { dinâmica } \\
\end{array}$ & Subvenção \\
\hline $\begin{array}{l}\text { Políticas } \\
\text { Nacionais }\end{array}$ & $\begin{array}{l}\text { Emissão de gases do efeito } \\
\text { estufa }\end{array}$ & $\begin{array}{l}\text { Atividades } \\
\text { degradantes }\end{array}$ & $\begin{array}{l}\text { Negativa, não } \\
\text { pecuniária e } \\
\text { dinâmica } \\
\end{array}$ & Subvenção \\
\hline $\begin{array}{l}\text { Políticas } \\
\text { Nacionais }\end{array}$ & $\begin{array}{l}\text { Mitigação dos efeitos da } \\
\text { mudança climática }\end{array}$ & & $\begin{array}{l}\text { Positiva, não } \\
\text { pecuniária e } \\
\text { dinâmica } \\
\end{array}$ & Subvenção \\
\hline $\begin{array}{l}\text { Políticas } \\
\text { Nacionais }\end{array}$ & $\begin{array}{l}\text { Redução da pressão das } \\
\text { florestas nativas }\end{array}$ & & $\begin{array}{l}\text { Positiva, não } \\
\text { pecuniária e } \\
\text { dinâmica }\end{array}$ & Subvenção \\
\hline $\begin{array}{l}\text { Políticas } \\
\text { Nacionais }\end{array}$ & $\begin{array}{l}\text { Emissão de gases de efeito } \\
\text { estufa }\end{array}$ & $\begin{array}{l}\text { Atividades } \\
\text { degradantes }\end{array}$ & $\begin{array}{l}\text { Negativa, não } \\
\text { pecuniária e } \\
\text { dinâmica }\end{array}$ & $\begin{array}{l}\text { Regulamentação, } \\
\text { subvenção e } \\
\text { mercado }\end{array}$ \\
\hline $\begin{array}{l}\text { Incentivo } \\
\text { Fiscal }\end{array}$ & $\begin{array}{l}\text { Indisponibilidade de } \\
\text { produtos florestais para a } \\
\text { exploração econômica }\end{array}$ & $\begin{array}{l}\text { Exploração } \\
\text { excessiva }\end{array}$ & $\begin{array}{l}\text { Negativa, pecuniária } \\
\text { e dinâmica }\end{array}$ & Subvenção \\
\hline $\begin{array}{l}\text { Incentivo } \\
\text { Fiscal }\end{array}$ & $\begin{array}{l}\text { Serviços ambientais } \\
\text { decorrentes do cultivo de } \\
\text { florestas plantadas }\end{array}$ & & $\begin{array}{l}\text { Positiva, não } \\
\text { pecuniária e } \\
\text { dinâmica }\end{array}$ & Subvenção \\
\hline
\end{tabular}

Fonte: Dados da Pesquisa (2018).

Ressalva-se que não se pretende analisar a efetividade da aplicação da legislação, mas apenas o conceito atribuído, ou seja, a externalidade à qual se tem a intenção de resolver e a forma de solução proposta pela legislação.

As externalidades reconhecidas no âmbito da legislação brasileira são predominantemente relativas à indisponibilidade dos recursos naturais, à redução dos serviços ambientais e aos efeitos climáticos. A regulamentação e a subvenção são os dois principais mecanismos de solução apontados. 
A regulamentação trata da proibição de uso dos recursos naturais, como no caso das Unidades de Conservação de proteção integral ou da regulamentação do uso destes, como no caso do controle da supressão de vegetação ou no regime de reserva legal. A subvenção ocorre a partir de incentivos fiscais voltados, principalmente, para o reflorestamento. Estes incentivos também podem ocorrer para preservação.

As diversas políticas nacionais voltadas para o florestamento e reflorestamento, a política de incentivos fiscais e a própria Política Nacional sobre Mudança do Clima (PNMC), reconhecem como solução da externalidade o reflorestamento. Este contribui para a mitigação dos efeitos climáticos e pode ser favorável para a redução da pressão sobre a floresta nativa, gerando menor impacto ambiental, além de contribuir com alguns benefícios, como a garantia de serviços ambientais. A subvenção é a estratégia predominante para a solução das externalidades caracterizadas sob esta perspectiva.

Em relação às florestas nativas, a proteção integral é recomendada pela legislação em diversas situações, principalmente aquelas relacionadas à conservação de outros recursos ambientais importantes, como a água e a proteção de espécies ameaçadas de extinção. O uso sustentável apresenta-se como alternativa na tentativa de conciliação entre desenvolvimento econômico e preservação. Em virtude, contudo, da complexidade dos aspectos envolvidos na preservação dos recursos naturais, os efeitos prolongados e difusos dos prejuízos da degradação destes à regulamentação apresentam-se como a estratégia recorrente para a solução das externalidades caracterizadas a partir desta perspectiva.

Em relação à classificação das externalidades, a pecuniaridade somente é associada ao produto florestal comercializado, como a lenha e a madeira, uma vez que se refere à garantia da disponibilidade destes produtos, o que impede a ocorrência de impactos nos preços do produto.

A complexidade do tratamento das externalidades florestais e a difusão desta para grande número de agentes com efeitos futuros incertos, caracteriza a externalidade florestal como dinâmica.

\section{Análise Geral das Externalidades}

A partir da análise conjunta dos dois grupos de documentos, observa-se semeIhança quanto à caracterização e indicação de solução para as externalidades florestais identificadas. Estas referem-se, principalmente, a quatro aspectos: serviços ambientais (disponibilidade ou indisponibilidade), recursos naturais (preservação ou degradação), efeitos climáticos (emissão ou absorção e estoque de gases de efeito estufa) e produtos madeireiros (disponibilidade ou escassez).

As circunstâncias da ação antropogênica que geram externalidade florestal são: o uso sustentável da florestal e o reflorestamento ou recuperação de área florestal, as quais ocasionam externalidades positivas, e a exploração de recursos florestais e a conversão do solo para uso alternativo, as quais geram externalidades negativas. Os mecanismos de solução identificados das externalidades nos dois conjuntos de documentos são: regulamentação, subvenção, taxação e mercado do direito de poluir. 
Ao estabelecer a análise para serviços ambientais e recursos naturais, constata-se como principais mecanismos de solução a regulamentação e a subvenção. Os mecanismos de mercado e a mudança de regime de propriedade, por meio da desapropriação em favor do Estado, de áreas de interesse ecológico, são menos citados.

Há uma perspectiva diferente na percepção de externalidade e na aplicação dos mecanismos de solução em comparação com a teoria da externalidade. Por exemplo, na perspectiva de mercado a solução da externalidade, para Coase (1960), por intermédio da livre-negociação entre agentes e com direitos de propriedade claramente definidos, pode ser mediante a internalização, quando o agente causador da externalidade soluciona o problema, ou por meio da indenização ao agente afetado. Para a questão ambiental, observa-se nos discursos contidos nos dois grupos de documentos que há sempre a necessidade de solucionar a externalidade. A solução da externalidade, mediante a compra dos direitos de poluir, ocorre pela aquisição de título de compensação. Deste modo, acontece uma compensação ambiental, ou seja, uma externalidade positiva para compensar uma externalidade negativa. Particularmente a esse aspecto há críticas, como as apresentadas por Sandel (2012), que afirma que "os críticos das emissões de gás carbônico costumam compará-los às indulgências, os pagamentos em dinheiro que os pecadores faziam à Igreja medieval para compensar suas transgressões" (p. 78)

Além da questão moral envolvida, este aspecto pode ser decorrente dos custos de transação para a solução via compensação econômica. Os efeitos das externalidades florestais negativas são complexos e dinâmicos (características da externalidade florestal), sendo difícil determinar os seus futuros impactos. Esta incerteza eleva os custos de transação a ponto de considerar mais prudente a compensação para os afetados pela externalidade mediante a restituição das condições ambientais e não pela indenização econômica. A exigência da restituição das condições ambientais é decorrente da regulamentação, não sendo uma obrigação definida nos mecanismos de mercado, quando estes são baseados na livre-negociação entre agentes.

Dentro das perspectivas de solução, a regulamentação é citada na maioria dos documentos internacionais. Nas Conferências Mundiais a regulamentação ganha ênfase como mecanismo de solução indicado e busca a conciliação entre desenvolvimento e preservação. Estas conferências atuam principalmente para atender a disponibilidade dos recursos naturais e a garantia dos serviços ambientais. Nestas, o papel do Estado é essencial no cumprimento dos objetivos preservacionistas. Ao, contudo, reconhecer a necessidade de crescimento econômico dos países em desenvolvimento, a atuação do Estado deve também considerar questões econômicas. É nesta dualidade que emergem as sugestões para solução dos problemas ambientais.

Analisando a natureza recíproca do problema da externalidade, conforme propõe Coase (1960), é possível verificar que a definição dos direitos de propriedade é pautada no direito sobre o solo e sobre os recursos florestais, principalmente madeireiros. 0 uso indiscriminado dos recursos, todavia, pode gerar prejuízos aos serviços ambientais. Conforme Coase (1960, p.7), é necessário compreender se “(...) a atividade nociva é ou não responsabilizável pelos prejuízos que causa (...)”. A solução pode vir com a atribuição do direito de propriedade a uma das partes ou com a regulamentação. Esta última, como instrumentos de solução das externalidades, é empregada para garantir a prestação destes serviços ambientais pelas florestas. 
Dentro da perspectiva de solução das externalidades florestais, a regulamentação é uma forma de definir adequadamente a abrangência dos direitos de propriedade. Os direitos de propriedade, aplicados à questão florestal, estão pautados no direito sobre a propriedade do solo onde localizam-se as florestas. Não há definição do direito privado para os bens públicos, como os serviços ambientais. A solução das externalidades, entretanto, atua para a solução de problemas causados a estes.

Os fins exclusivamente preservacionistas da ação Estatal, por meio de regulamentação, são uma recomendação recorrente. No caso da Convenção sobre Diversidade Biológica (CDB) de 1992, recomenda-se a delimitação de áreas protegidas para garantir a biodiversidade para gerações presentes e futuras. A legislação segue tal recomendação ao estabelecer as áreas de preservação permanente nas propriedades privadas e unidades de conservação, que podem ser em propriedades privadas ou desapropriadas pelo Estado. Nestas áreas é proibida a exploração de recursos florestais e a conversão do solo para uso alternativo. Quando a legislação emprega a regulamentação a partir de proibição e regulação da ação, ela define o direito de propriedade privada. Neste caso, tem a intenção de preservar o direito ambiental para os indivíduos que não podem participar da negociação de solução da externalidade, e, deste modo, preserva os serviços ambientais para a população.

Além da proibição ou regulação, pode-se empregar a autorização ou licenciamento de uso dos recursos florestais, reforçando a característica de controle direto do Estado constante em ambos os grupos de documentos. O mecanismo de enforcement presente, principalmente, na lei de crimes ambientais, por exemplo, favorece a atuação do Estado. O Cadastro Ambiental Rural (CAR), por ser um instrumento de controle da informação, também favorece o enforcement e, consequentemente, a ação do Estado. Neste caso, a regulação das atividades, dentro das propriedades privadas, principalmente em relação à conversão do solo para uso alternativo, torna-se mais fácil de ser controlada ou punida.

O uso da regulamentação é mais frequente na legislação brasileira em comparação com os demais mecanismos de solução das externalidades. Salienta-se que os documentos internacionais são produzidos a partir do debate e de decisões de representantes de nações. O uso da regulamentação, portanto, pode estar associado ao fato de o Estado possuir maior controle deste instrumento, empregando-o para atender às deliberações e normatizações acordadas.

A regulamentação de proibição de uso pode ser substituída pela desapropriação. A Lei 9.985 (BRASIL, 2000), que trata da definição de unidades de conservação, permite ou obriga o Estado a desapropriar áreas de interesse ecológico. Neste caso, o Estado arca com os custos da preservação, tanto pela compra da área, por meio da desapropriação, quanto pelos custos de sua manutenção, incluindo a fiscalização, para evitar a subtração ilegal de produtos florestais ou a degradação por outras formas, configuradas como crime da ação antropogênica. Há a clara definição dos direitos de propriedade, pois a propriedade é estatal. Na perspectiva de Coase (1960), a clara atribuição dos direitos de propriedade permite que os agentes envolvidos encontrem uma solução eficiente para a questão. No caso das Unidades de Conservação, porém, quando há a 
mudança de regime de propriedade de privado para Estatal, com a desapropriação, a solução da externalidade não ocorre pelo mecanismo de mercado, mas, sim, pela opção do Estado, que passa a ser proprietário da área.

A subvenção aparece de duas formas nos documentos internacionais. Há a recomendação da atuação do Estado para a realização da mesma com fins preservacionistas. Há também a subvenção entre as Nações por intermédio de fundos mundiais, em que os principais contribuintes são os países desenvolvidos. Esta subvenção emerge do debate sobre a responsabilidade pela atual situação de degradação ambiental, em que os países que alcançaram o desenvolvimento são os que mais poluíram e degradaram, e continuam sendo os que mais poluem e degradam. A aceitação de um nível de poluição parece necessário para alcançar o desenvolvimento. A escolha do caminho a ser percorrido para alcançar o desenvolvimento por meio da Economia Verde, bastante citado na Declaração de 2012 (CNUDS, 2012), incorre no financiamento de novas formas de atuação e de desenvolvimento econômico, que são não poluentes ou menos poluentes que as formas tradicionais empregadas pela economia mundial. Estas formas são financiadas nos países que ainda não alcançaram altos níveis de desenvolvimento, onde é possível encontrar menores custos para mudança ou estabelecimento da matriz tecnológica.

O mecanismo de mercado, empregado na solução dos problemas relacionados aos serviços ambientais e/ou recursos naturais, é evidenciado na legislação florestal pela Cota de Reserva Ambiental. Esta é um título que flexibiliza o cumprimento da obrigação de Reserva Legal na propriedade privada. Deste modo, ao invés de cumprir tal obrigação, o proprietário pode adquirir um título que representa que a mesma está sendo cumprida em outro local. Há, portanto, a solução via mecanismo de mercado. Esta é semelhante ao mercado do direito de poluir, pois a aquisição da Cota de Reserva Ambiental ocorre para que o proprietário possa usufruir da totalidade de sua propriedade, exceto as áreas de preservação permanente.

Para as externalidades associadas aos produtos madeireiros, aplicam-se a regulamentação e a subvenção para atendimento da disponibilidade dos mesmos. A regulamentação ocorre, principalmente, pelo uso do manejo sustentável, recomendado pelos documentos internacionais e previsto no Código Florestal Brasileiro (BRASIL, 2012). A subvenção é sugerida para que o Estado apoie ações, principalmente as voltadas ao reflorestamento. Na legislação brasileira a subvenção para reflorestamento é citada no Código Florestal (BRASIL, 2012) e nas leis que estabelecem incentivos e políticas para exploração das atividades de silvicultura.

As externalidades relacionadas aos efeitos climáticos estão baseadas nas formas de solução relacionadas à regulamentação, subvenção e mercado.

O mercado de direitos de poluir, tanto a partir da legislação quanto desde os documentos internacionais, possui três características fundamentais que compõem a sua essência: a necessidade de regulamentação, a atribuição dos direitos de propriedade sobre serviços ambientais e a inexistência de benefícios adicionais à sociedade, uma vez que os títulos são negociados apenas para compensar a poluição gerada.

A regulamentação, primeira característica, atribui autorização para poluir em um determinado nível e, após este nível, para o caso dos documentos analisados, determina que sejam adquiridos títulos de compensações realizadas em outras atividades 
ou locais. Por exemplo, as emissões certificadas de um projeto de MDL realizado em uma região, podem ser utilizadas para compensar as obrigações de evitar a poluição em outra região. Conforme Richards (2000), o mercado de carbono depende também de instituições eficientes para mensuração e comercialização adequadas.

A segunda característica é a atribuição dos direitos de propriedade ao agente para que possa usufruir dos serviços ambientais gerados pela floresta. $\mathrm{O}$ mercado dos direitos de poluir, quando não considera a venda do título de autorização de poluição, vende títulos de compensação de poluição, ou seja, de benefícios proporcionados por ações dos agentes em outros locais ou atividades. Estes podem ser caracterizados como serviços ambientais para a questão florestal. Neste caso, trata-se de um bem que não possibilita a exclusão dos demais agentes dos benefícios gerados. Este produto, portanto, somente será incorporado ao mercado, ou seja, poderá ser explorado economicamente, se houver a aplicação do princípio do poluidor pagador para o adquirente dos títulos. A aplicação do princípio do poluidor pagador não ocorrerá em razão da taxação, mas exigirá deste a busca no mercado pela compensação. Para o gerador da externalidade positiva, mesmo diante da impossibilidade da exclusão de outros agentes dos beneficiários, a necessidade de compensação imposta ao poluidor pagador permite a exploração econômica. Conforme explica Nusdeo (2008), há uma apropriação de um bem caracterizado anteriormente como bem livre.

Destaca-se, como terceira característica, que não há adição de benefícios para a sociedade quando a compensação é negociada, pois a poluição continua sendo gerada pelo adquirente do título. A atividade realizada que dá origem aos benefícios ambientais e, consequente, à emissão do título utilizado na compensação, não poderá gerar benefícios ambientais adicionais à sociedade, uma vez que estas externalidades positivas são negociadas apenas para compensar as externalidades negativas de outras atividades. A demanda do mercado constitui-se da obrigação de compensação imposta ao poluidor. Diferentemente do que ocorre com a regulamentação, que exige a preservação dos recursos naturais sem vínculo com a necessidade de compensação de poluição.

As diversas políticas nacionais voltadas para o florestamento e reflorestamento, a política de incentivos fiscais e a própria PNMC, reconhecem o reflorestamento como solução das externalidades dos efeitos climáticos. Este contribui para a mitigação dos efeitos climáticos e pode ser favorável para a redução da pressão sobre a floresta nativa, gerando menor impacto ambiental, além de contribuir com alguns benefícios, como a garantia de serviços ambientais. A subvenção é a estratégia predominante para a solução das externalidades caracterizadas sob esta perspectiva.

A regulamentação é apropriada, principalmente, para a conservação das florestas, as quais são sumidouros de gases de efeito estufa. Na legislação brasileira a obtenção dos serviços ambientais, associados aos efeitos climáticos, é prevista nas Políticas Nacionais e no Código Florestal (BRASIL, 2012).

De forma geral, busca-se evitar as externalidades negativas a partir da regulamentação, e incentiva-se medidas compensatórias ou a ocorrência de externalidades positivas por meio da subvenção. O mercado é um instrumento aplicado apenas para a solução das externalidades climáticas e como mecanismo de flexibilização no cumprimento de uma regulamentação, no caso da Cota de Reserva Ambiental. 


\section{CONSIDERAÇÕES FINAIS}

A visão de externalidade para a questão florestal diante dos documentos analisados, é assumida a partir de quatro circunstâncias de ação antropogênica. As duas primeiras - o uso sustentável da floresta e a recuperação de áreas florestais ou o reflorestamento - geram externalidades positivas, exploração dos recursos florestais, porém sem a conversão do solo florestal para outro uso, e a conversão para uso alternativo do solo. Estas duas ações eliminam os benefícios ambientais proporcionados pela floresta, portanto geram externalidades negativas.

A geração de externalidade a partir das atividades econômicas citadas nos dois conjuntos de documentos refere-se, principalmente, a quatro aspectos: serviços ambientais (disponibilidade ou indisponibilidade), recursos naturais (preservação ou degradação), efeitos climáticos (emissão ou absorção e estoque de gases de efeito estufa) e produtos madeireiros (disponibilidade ou escassez).

Identificou-se algumas características predominantes da externalidade florestal semelhantes nos dois conjuntos de documentos, apesar da forma distinta de abordagem. Estas características referem-se: a) ao equilíbrio dinâmico das externalidades florestais; b) às externalidades positivas, que estão associadas aos serviços ambientais ou à redução da pressão às florestas plantadas; c) à solução das questões ambientais vinculadas às florestas predominantemente a partir da regulamentação e subvenção; d) à pecuniariedade caracterizada somente para a escassez dos produtos florestais comercializados, como lenha e madeira; e e) à configuração complexa para solução dos problemas climáticos, apesar de a solução ocorrer mediante mais de um mecanismo, entre eles o mercado.

As externalidades florestais identificadas possuem característica de equilíbrio dinâmico. Os impactos ambientais podem ser de difícil recuperação e com efeitos prolongados, estendendo-se, em vários casos, para gerações futuras, em virtude de a condição de recuperação do meio ambiente depender de longo período de tempo. As soluções tecnológicas ou inexistem ou são inviáveis economicamente para problemas que são recorrentes em diversos espaços geográficos. Além disso, há também a indisposição política que dificulta obter consenso sobre os temas ambientais, pois ela sofre pressão direta de agentes interessados em aspectos que não são conciliatórios com a manutenção do meio ambiente em suas condições naturais.

As externalidades positivas são associadas com os serviços ambientais e com a redução da pressão sobre florestas nativas. Nesta segunda situação, ao conservar as florestas nativas, há a garantia dos serviços ambientais das florestas, portanto vinculando-se uma externalidade a outra. As externalidades florestais relativas aos serviços ambientais, tais como conservação de ciclos hidrológicos, preservação do patrimônio genético, da fauna e da flora, por exemplo, são complexas e difusas em razão da ampla gama de serviços que podem ser prestados. Observa-se em cada documento citações de diferentes benefícios ambientais que a floresta pode proporcionar. A complexidade está relacionada com a dificuldade de mensuração precisa dos efeitos negativos no meio ambiente, quando a atividade gera externalidade negativa e da impossibilidade de exclusão de beneficiários dos serviços ambientais, quando a atividade gera externalidade positiva. 
Quando há complexidade, a recomendação da solução, proposta por Coase (1960), é a regulamentação. Esta forma de solução é recorrente, sendo citada para a maioria das externalidades em ambos os conjuntos de documentos. A partir da conservação da floresta, os benefícios ambientais serão garantidos sem a necessidade de determinar quais benefícios e quais agentes serão favorecidos por estes. Cumpre-se o papel do Estado de garantir os benefícios ambientais a todos.

Constatou-se nos documentos analisados uma predominância de recomendações (a partir dos documentos internacionais) e de emprego (a partir da legislação) da subvenção e da regulamentação como formas de solução das externalidades. $O$ emprego da subvenção pelo Estado reforça o reconhecimento da reponsabilidade deste em garantir a conservação florestal.

A terceira característica observada nos dois conjuntos de documento é a preocupação com a escassez dos recursos florestais para exploração econômica. Esta caracteriza uma externalidade pecuniária, pois os resultados da existência e do tratamento desta impactam diretamente na oferta de produtos ao mercado. Neste caso, a subvenção e a regulamentação são as formas de atuação do Estado para a solução. O mercado não pode ser considerado, pois a absorção dos efeitos negativos pelo mercado é que caracteriza a externalidade pecuniária.

A quarta característica é uso das florestas para evitar ou tratar os efeitos da mudança climática. Este papel, exercido pelas florestas, pode ser protegido por meio de mecanismos de regulamentação, evitando aumento das emissões por desmatamento e subvenção a partir do incentivo ao reflorestamento ou conservação das florestas, e por intermédio do mercado, com do comércio de créditos de carbono.

A reflexão importante a ser feita é que os benefícios ambientais da floresta sempre existiram, assim como os prejuízos ambientais do desmatamento ou da exploração da floresta são oriundos das atividades econômicas. Quando se proíbe ou regulamenta as atividades nocivas para evitar as externalidades negativas, está exigindo-se a internalização destas pelo seu gerador. Ao utilizar-se de mecanismos de mercado tem-se de considerar que comercializar a externalidade positiva, relativa a serviços ambientais, parece uma solução para permitir que se comercialize o que sempre foi direito comum. Ponderações para instalação de mecanismos de mercado para a solução das externalidades florestais, portanto, devem considerar os impactos sociais decorrentes de seu uso.

O estudo buscou a compreensão das externalidades e formas de solução indicadas na legislação brasileira e nos documentos internacionais. A efetividade desta solução, contudo, não foi considerada na análise. Como proposta de estudos futuros sugere-se a investigação da eficiência das propostas de soluções para as externalidades identificadas.

\section{REFERÊNCIAS}

ASAFU-ADJAYE, J. Environmental economics for non-economists: techniques and policies for sustainable development. 2. ed. Singapore: World Scientific, 2005. Disponível em: https://books.google.com. $\mathrm{br} /$ books? id=IwUKDaGiO5wC\&pg=PA72\&lpg=PA72\&dq=\%22classification+of+externalities\%22\&source=bl\&ots=p_8vqHanUi\&sig=bQieR3xHqbJ9sDsQI7v5F9_NxBQ\&hl=pt-BR\&sa=X\&ved=0ahUKEwi-IMv7st7JAhUDOCYKHRmwAOYQ6AEIJDAB\#v=onepage\&q\&f=false. Acesso em: 10 dez. 2018.

BARNES, R. Property Rights and Natural Resources. Oxford: Hart, 2009. 
BITHAS, K. Sustainability and externalities: is the internalization of externalities a suficiente condition for sustainability? Ecological Economics, v. 70, n. 10, p. 1.703-1.706, ago. 2011. Disponível em: http://www. sciencedirect.com/science/article/pii/S0921800911002035. Acesso em: 14 abr. 2019.

BOTTARO, G.; ROCO, L.; PETTENELLA, D.; MICHELETTI, S.; VANHULST, J. Forest Plantations' Externalities: An Application of the Analytic Hierarchy Process to Non-Industrial Forest Owners in Central Chile. Forests, v. 9, n. 3, p. 1-21, mar. 2018. Disponível em: https://www.mdpi.com/1999-4907/9/3/141. Acesso em: 27 jul. 2019.

BRASIL. Lei 4.771, de 15/09/1965. Institui o Novo Código Florestal. 1965. Disponível em: http://www2. camara.leg.br/legin/fed/lei/1960-1969/lei-4771-15-setembro-1965-369026-publicacaooriginal-1-pl.html. Acesso em: 20 jan. 2016.

BRASIL. Lei 9.985, de 18/07/2000. Regulamenta o art. 225, par. 1ํ, incisos i, ii, iii e vii da Constituição Federal, institui o sistema nacional de Unidades de Conservação da Natureza e dá outras providências. 2000. Disponível em: http://www.planalto.gov.br/ccivil_03/LEIS/L9985.htm. Acesso em: 20 jan. 2016.

BRASIL. Lei n. 12.651, de 25 de maio de 2012. Dispõe sobre a proteção da vegetação nativa; altera as Leis nos 6.938, de 31 de agosto de 1981, 9.393, de 19 de dezembro de 1996, e 11.428, de 22 de dezembro de 2006; revoga as Leis nos 4.771, de 15 de setembro de 1965, e 7.754, de 14 de abril de 1989, e a Medida Provisória no 2.166-67, de 24 de agosto de 2001; e dá outras providências. 2012. Disponível em: http:// www.planalto.gov.br/ccivil_03/_ato2011-2014/2012/lei/l12651.htm. Acesso em: 2 fev. 2015.

COASE, R. H. The Problem of Social Cost. Journal of Law and Economics, v. 3, p. 1-44, out. 1960. Disponível em: http://www.jstor.org/stable/724810. Acesso em: 3 mar. 2019.

CORBETTA, P. Social research: theory, methods and techniques. Bolonha: Sage, 2003.

FAUCHEUX, S.; NOËL, J. F. Economia dos recursos naturais e do meio ambiente. Lisboa: Instituto Piaget, 1995.

FEARNSIDE, P. M. Desmatamento na Amazônia: dinâmica, impactos e controle. Acta Amaz., Manaus, v. 36, n. 3, 2006. Disponível em: http://www.scielo.br/scielo.php?script=sci_arttext\&pid=S0044-59672006000300018\&lng=pt\&nrm=iso. Acesso em: 10 ago. 2019.

FLICK, U. Introdução à pesquisa qualitativa. 3. ed. Porto Alegre: Artmed, 2009.

GODOY, A. S. Pesquisa qualitativa: tipos fundamentais. Rev. Adm. Empres., São Paulo, v. 35, n. 3, jun. 1995. Disponível em: http://www.scielo.br/scielo.php?script=sci_arttext\&pid=S0034-75901995000300004\&lng=pt\&nrm=iso. Acesso em: 3 ago. 2019.

GODOY, S. G. M.; SAES, M. S. M. Cap-and-trade e projetos de redução de emissões: comparativo entre mercados de carbono, evolução e desenvolvimento. Ambient. Soc., São Paulo, v. 18, $\mathrm{n}$. 1, p. 135-154, mar. 2015. Disponível em: http://www.scielo.br/scielo.php?script=sci_arttext\&pid=S1414-753X2015000100009\&Ing=pt\&nrm=iso. Acesso em: 17 jun. 2019.

HOLCOMBE, R.; SOBEL, R. Public policy toward pecuniary externalities. Public Finance Review, v. 29, n. 4, p. 304-325, jul. 2001. Disponível em: https://www.amherst.edu/system/files/media/1219/Holcombe\%2520Pecuniary\%2520Externalities.pdf. Acesso em: 20 maio 2019.

LEMOS, A. L. F.; VITAL, M. H. F.; PINTO, M. A. C. As florestas e o painel de mudanças climáticas da ONU. BNDES Setorial, n. 32, p. 153-192, 2010. Disponível em: http://www.bibliotecaflorestal.ufv.br/handle/123456789/4014. Acesso em: 6 fev. 2019.

MANKIW, N. G. Princípios de microeconomia. 3. ed. São Paulo: Pioneira Thomson Learning, 2005.

MERLO, M.; BRIALES, E. R. Public goods and externalities linked to Mediterranean forests: economic nature and policy. Land Use Policy, v. 17, n. 3, p. 197-208, 2000. Disponível em: http://www.sciencedirect. com/science/article/pii/S026483770000017X. Acesso em: 21 jan. 2019.

MILGROM, P.; ROBERTS, J. Economics, Organization and Management. New Jersey: Prentice Hall, 1992.

NOBRE, A. D. O futuro climático da Amazônia: relatório de avaliação científica. São José dos Campos: Articulación Regional Amazónica (ARA), 2014. Disponível em: http://www.ccst.inpe.br/wp-content/uploads/2014/10/Futuro-Climatico-da-Amazonia.pdf. Acesso em: 20 jan. 2019.

NOBRE, M. Desenvolvimento sustentado e problemática ambiental. Lua Nova, São Paulo, n. 47, p. 137-156, ago. 1999. Disponível em http://www.scielo.br/scielo.php?script=sci_arttext\&pi$\mathrm{d}=$ S0102-64451999000200008\&lng=pt\&nrm=iso. Acesso em: 12 abr. 2019.

NUSDEO, A. M. O. O papel dos mercados e dos direitos de propriedade na proteção ambiental. In: SELA SEMINARIO EN LATINOAMÉRICA DE TEORÍA CONSTITUCIONAL Y POLÍTICA, 2008, Buenos Aires. Anais [...]. Buenos Aires: eYls, 2008. Disponível em: http://digitalcommons.law.yale.edu/cgi/viewcontent.cgi?article=1061\&context=yls_sel. Acesso em: 10 abr. 2019. 
PAAVOLA, J.; ADGER, W. Neil. New Institutional Economics and the environment: conceptual foundations and policy implications. CSERGE Working Paper EDM 02-06. Norwich: Centre for Social and Economic Research on the Global Environment (CSERGE), University of East Anglia, Norwich, 2002. Disponível em: http://citeseerx.ist.psu.edu/viewdoc/download?doi=10.1.1.200.914\&rep=rep1\&type=pdf. Acesso em: 3 mar. 2019.

PIGA, T. R.; MANSANO, S. R. V. Sustentabilidade ambiental e história: uma análise crítica. Revista Perspectivas Contemporâneas, v. 10, n. 2, p. 174-195, maio/ago. 2015. Disponível em: http://revista.grupointegrado.br/revista/index.php/perspectivascontemporaneas/article/view/1856/734. Acesso em: 12 abr. 2019.

PIGOU, A. C. The Economics of Welfare. The Online Library of Liberty. 1920. Disponível em: http://oll. libertyfund.org/Home3/EBook.php?recordID=0316. Acesso em: 10 abr. 2019.

PRICE, C. Sustainable forest management, pecuniary externalities and invisible stakeholders. Forest Policy and Economics, v. 9, n. 7, p. 751-762, abr. 2007. Disponível em: http://www.sciencedirect.com/science/ article/pii/S1389934106001080. Acesso em: 10 abr. 2019.

RICHARDS, M. Can Sustainable Tropical Forestry be Made Profitable? The Potential and Limitations of Innovative Incentive Mechanisms. World Development, v. 28, n. 6, p. 1.001-1.016, 2000. Disponível em: http://www.sciencedirect.com/science/article/pii/S0305750X00000036?np=y. Acesso em: 12/04/2019.

SANDEL, M. O que o dinheiro não compra. Rio de Janeiro: Civilização Brasileira, 2012.

SIEBERT, H. Economics of the Environment: Theory and Policy. 7. ed. Berlin: Springer, 2008.

SOLIÑO, M.; PRADA, A.; VÁZQUEZ, M. X. Green electricity externalities: Forest biomass in an Atlantic European Region. Biomass and Bioenergy, v. 33, n. 3, p. 407-414, mar. 2009. Disponível em: http://www. sciencedirect.com/science/article/pii/S0961953408002092. Acesso em: 20 abr. 2019.

VARIAN, H. R. Microeconomic analysis. 3. ed. New Yourk: W.W. Norton \& Company, 1992. Disponível em: http://mileslight.com/armenia/Varian-MicroeconomicAnalysis.pdf. Acesso em: 12 abr. 2019. 